\title{
Use of Rice Straw and Black Gram Straw in Fodder Based Goat's Diets in the Hills of Nepal
}

\author{
Chet R. Upreti ${ }^{* 1}$, Bahadur S. Kuwar ${ }^{2}$ and Shambhu. B. Panday ${ }^{3}$ \\ ${ }^{1}$ Agricultural Research Station (Goat), Bandipur, Tanahun \\ ${ }^{2}$ Agricultural Research Station (Goat), NARC, Bandipur, Tanahun (formerly) \\ ${ }^{3}$ Nepal Agricultural Research Council, Singhadurbar Plaza, Kathmandu \\ * Current address: Animal Nutrition Division, Khumaltar, Lalitpur, PO Box 1950, \\ $<$ crupreti@yahoo.com>
}

\begin{abstract}
The aim of this study was to investigate the possible use of crop residue such as rice straw and black gram straw (Kushauro) in hill goats' diet. Twenty male and female goats of age 69 months were divided into 4 dietary groups. Animal of first diet groups $\left(D_{1}\right)$ were fed with fodder leaves (Khanyu) only, second diet group $\left(\mathrm{D}_{2}\right)$ with $20 \%$ rice straw + fodder tree foliage, third diet group $\left(\mathrm{D}_{3}\right)$ with $20 \%$ rice straw + fodder tree foliage + concentrate @ $1 \%$ of body weight, and fourth diet group $\left(\mathrm{D}_{4}\right)$ fodder tree foliage $+15 \%$ rice straw $+5 \%$ black gram straw + concentrate @ $1 \%$ of body weight meet to the daily requirement. These rations were fed to animals of individual diet group for 150 days. Daily feed intake, daily weight change was recorded. Body weight was taken at the beginning of the experiment, at the end of experiment and 15 days interval. The result showed that there was significant difference $(\mathrm{P}<0.05)$ between different dietary groups for average daily gain (ADG). The highest ADG was observed in $\mathrm{D}_{3}(19.6 \pm 4.33)$, followed by $\mathrm{D}_{2}(12.67 \pm 1.38 \mathrm{~g} / \mathrm{d})$ and $\mathrm{D}_{4}(11.73 \pm 1.78 \mathrm{~g} / \mathrm{d})$. The lowest ADG was found in $\mathrm{D}_{1}(10.8 \pm 1.87 \mathrm{~g} / \mathrm{d})$. The result indicated that $20 \%$ rice straw can be used in goat diet with supplementary diet of concentrate @ 1\% of body weight, and foliage of Khanyu as a basal diet. Feeding only fodder tree foliage is not suitable to get higher ADG in stall-feeding management.
\end{abstract}

Key words: Average daily weight gain, black gram straw, fodder tree foliage, rice straw, stall-feeding

\section{INTRODUCTION}

Rice straw is a crop residue derived from rice production. It serves as a major feed for ruminants. (Dixon 1985). Annually 10.7 million metric ton rice straw is produced in the country, out of which the large ruminants such as cattle and buffalo use $82.4 \%$. The remaining balance $17.6 \%$ rice straw is available for other uses. If this surplus straw could be used for goat feeding, it will substantially reduce the feed scarcity problem in the country (Pande 1997), particularly during the winter. But the available straw is low in nutrients content and is highly lignified (Sharma et al 1995, Chenost and Kayouli 1997). Therefore, there is a need to improve in quality in terms of its use and make use of straw in animal diet. Therefore it is important to supplement tree foliage and concentrate feed (compounded cereal grain, legume and their by-products) to make the best utilization of the crop residue. Work carried out in other countries have shown that feeding 30 percent rice straw with leucaena leaves $(50 \%)$ and rice bran $(20 \%)$ as supplements can to maintain $68.6 \mathrm{~g} / \mathrm{d}$ daily weight gain (Rasjit and Perez 1980). Upreti 2004 recorded that if straw is treated with urea and fed ad lib with $20 \%$ Ipil-Ipil green foliage supplementation the ADG of 41.11 can be obtained in stall feed management system. Further, goats has higher rate of dry matter digestibility (DMD) with rice straw (Devendra 1988) that indicate possibility of incorporating rice straw in goat diet in certain proportion. Therefore, a study was conducted at ARS Bandipur using goats to investigate on the use of crop residues particularly rice straw (Oryza sativa) and black gram straw (Vigna mungo) with khanyu (Ficus semicordata) as basal diet. 


\section{MATERIALS AND METHODS}

Feeding experiment was conducted to evaluate the possible use of crop residue particularly the rice straw and black gram straw on the goats for stall-feeding system at ARS Bandipur during winter 2000. Tree foliage, Khanyu (Ficus semicordata) was fed as basal diet. Concentrate feed was offered (a) $1 \%$ of body weight of experimental goats.

\section{Experimental animals}

Sixteen female and four castrated male goats of 6 to 8 months of age were used in the experiment. The initial body weight (IBW) of animals ranged from 11 to $12 \mathrm{~kg}$. The breeds of goats were Khari, Jamunapari crosses $(50 \%$ Jamunapari $\times$ Khari), and Barbari crosses $(50 \%$ Barbari $\times$ Khari). They were drenched seven days before the experiment against internal parasite using Albendazole at recommended dose. Animals were also dipped against external parasites seven days before the drenching. Faecal sample were analyzed after seven days of drenching to assess the parasitic burden. These animals were then grouped into four groups on the basis of body weight in such a way that each breed and sex represents in each treatment group to reduce their possible effect of the sex and breed in the treatment. Animals were individually housed in metabolic crates affixed inside the experimental shed. The crates were measured 1.0 meter length, $0.45 \mathrm{~m}$ width and 1.0 meter height.

\section{Experimental diet}

Following diets were fed to the experimental animals to know the level of rice straw (Oryza sativa) and Black gram Kunauro (Phaseolus mungo) intake and body weight change.

$$
\begin{aligned}
& D_{1}=\text { Conventional feeding with fodder leaves only } \\
& D_{2}=20 \% \text { Rice straw }+ \text { fodder leaves } \\
& D_{3}=20 \% \text { Rice straw }+ \text { fodder leaves }+ \text { concentrate } 1 \% \text { of body weight } \\
& D_{4}=15 \% \text { Rice straw }+5 \% \text { black bean straw }+ \text { concentrate } 1 \% \text { of body weight }
\end{aligned}
$$

Locally available rice straw $(87.5 \% \mathrm{DM})$ was chaffed $(6 \mathrm{~cm}$ long) and incorporated in the diets at the percentage described in individual diet based on the daily DM requirement of animal. Feed formulation was done according to NRC recommendation to meet the daily nutrients requirement of $\mathrm{DM}=3 \%$ of body weight and $\mathrm{CP}=3 \mathrm{~g} / \mathrm{kg}$ body weight per day. Khanyou (Ficus semicardata) twigs with fresh green foliage were offered as main diet. Nutrient content of different feedstuffs is given in Table 1. Chaffed straw, fodder twigs and concentrate were offered in certain hourly interval in wooden box fixed at brisket height of metabolic pens. Fresh water was offered tree times a day. Daily intake of rice straw, fodder, black gram straw and concentrate was recorded for an experimental period of 150 days. A fixed level of concentrate was offered in $\mathrm{D}_{3}$ and $\mathrm{D}_{4} @ 1 \%$ body weight daily.

\section{Body weight measurement}

\section{Measurements taken}

The trial period was of 150 days after an adaptation period of 15 days. At the end of trial a digestibility trial was conducted for 7 days. Total feed intake was recorded daily in the morning at $09 \mathrm{hrs}$. Faeces and urine excreted was collected individually and recorded for the last 7 days of experimental period. The body weight of individual animal was taken at 15 days interval in the morning before feeding.

\section{Chemical analysis}

Dry matter $(\mathrm{DM})$ content of offered feed and faeces voided were determined by drying at $100^{\circ} \mathrm{C}$ for $24 \mathrm{~h}$ and organic matter $(\mathrm{OM})$ content was determined by ignition in the electronic furnace at $500^{\circ} \mathrm{C}$ for 6 hours. Representative samples of the feeds, faeces and urine were analyzed for proximate composition by AOAC 1990 and Goering and Van Soest (1970). The chemical composition of different feed ingredients used in the experiment is given in Table 1. 
Data were analyzed using analysis of variance as suggested by Snedecor and Cochran (1968) using Statistix version 1.0 Statistical package.

\section{RESULTS AND DISCUSSION}

Feedstuffs were analyzed for nutritive value using facilities available at Animal Nutrition Division, Khumaltar. The $\mathrm{CP}$ of rice straw was similar to the average figure as reported by Upreti and Shrestha 2006 and the CP content of black gram straw was (Vigna mungo) recorded $1 \%$ higher as reported by same authors.

Table 1. Chemical composition of different feedstuffs (\%DM basis)

\begin{tabular}{lrrrrrrrrr}
\hline Ingredients & DM & CP & OM & EE & NDF & ADF & ADL & H.CL. & CL \\
\hline Khanyou & 38.8 & 14.1 & 88.84 & 0.82 & 53.24 & 47.53 & 28.3 & 5.71 & 19.23 \\
Concentrate mixture & 87.53 & 15.3 & 93.53 & 4.84 & - & - & - & - & - \\
Rice straw (RS) & 87.5 & 4.5 & 81.31 & 0.36 & 74.91 & 50.54 & 21.12 & 24.37 & 29.42 \\
Black gram straw & 85.0 & 12.5 & 87 & 1.0 & - & - & - & - & - \\
\hline
\end{tabular}

DM, Dry matter. CP, Crude protein. OM, Organic matter. EE, Ether extract. NDF, Neutral detergent fiber. $A D F$, Acid detergent fiber. ADL, Acid detergent lignin. H.Cl, Hemi cellulose. Cl, Cellulose.

\section{Feed intake}

The nutrient intake of different diet groups is shown in Table 2. The DM intake was significantly different $(\mathrm{P}>0.05)$ between treatment groups. The highest DM intake $(503.85 \mathrm{~g} / \mathrm{d})$ was found in $\mathrm{D}_{3}$ followed by $\mathrm{D}_{4}(491.2 \mathrm{~g} / \mathrm{d})$, and $\mathrm{D}_{2}(484.1 \mathrm{~g} / \mathrm{d})$. Significantly lower $\mathrm{DM}$ intake was found in $\mathrm{D}_{1}$ $(440.31 \mathrm{~g} / \mathrm{d})$. These DM intakes were 3.63, 4.0, 3.85 and 3.95 percent of body weight of Diet 1, 2, 3 and 4 respectively. It indicated that incorporation of rice straw at the level of $20 \%$ of DM requirement did not affect significantly $(\mathrm{P}>0.05)$ on DM intake in goats similar as reported by Rasjit and Perez (1980).

The DM intake per kg live weight gain was significantly $(\mathrm{P}<0.05)$ lower in $\mathrm{D}_{3}(25.71 \mathrm{~kg})$, which was followed by $\mathrm{D}_{2}(38.22 \mathrm{~kg})$ and $\mathrm{D}_{1}(40.77 \mathrm{~kg})$. The highest DM intake per $\mathrm{kg}$ live weight gain was found in $\mathrm{D}_{4}(41.86 \mathrm{~kg})$. The lower $\mathrm{DM}$ required per $\mathrm{kg}$ live weight gain in $\mathrm{D}_{3}$ would be due to inclusion of concentrate mixture in the diet that has improved the digestibility of nutrients (Agrawal et al 1989).

Table 2. Nutrient intake of animals (g) of different treatment groups on DM basis

\begin{tabular}{|c|c|c|c|c|}
\hline \multirow[t]{4}{*}{ Nutrients } & \multicolumn{4}{|c|}{ Diets } \\
\hline & Fodder only & RS $20 \%+$ Fodder $80 \%$ & RS $20 \%+$ Fodder & RS $15 \%+$ Fodder \\
\hline & $\mathrm{D}_{1}$ & $\mathrm{D}_{2}$ & $(55 \%)+$ Concentrate & $(80 \%)+\operatorname{BGS}(5 \%)$ \\
\hline & & & $\mathrm{D}_{3}$ & $\mathrm{D}_{4}$ \\
\hline DM & $440.31^{\mathrm{a}}$ & $484.12^{\mathrm{b}}$ & $503.85^{b}$ & $491.18^{\mathrm{b}}$ \\
\hline $\mathrm{CP}$ & $57.24^{\mathrm{a}}$ & $49.54^{\mathrm{b}}$ & $34.04^{\mathrm{b}}$ & $50.75^{\mathrm{b}}$ \\
\hline $\mathrm{Ca}$ & 9.64 & 7.88 & 5.91 & 7.74 \\
\hline $\mathrm{P}$ & 1.01 & 1.11 & 1.75 & 1.08 \\
\hline$\%$ DM I & 3.63 & 4.0 & 3.85 & 3.95 \\
\hline $\mathrm{DMI}(\mathrm{g}) / \mathrm{W}^{0.75}$ & 67.74 & 74.36 & 73.23 & 74.31 \\
\hline \multicolumn{5}{|c|}{ Nutrient intake (kg) per kg LW gain } \\
\hline DM & $40.77^{\mathrm{a}}$ & $38.22^{\mathrm{a}}$ & $25.71^{b}$ & $41.86^{\mathrm{a}}$ \\
\hline $\mathrm{CP}$ & $5.3^{\mathrm{a}}$ & $3.91^{\mathrm{a}}$ & $1.74^{\mathrm{b}}$ & $4.32^{\mathrm{a}}$ \\
\hline
\end{tabular}

RS, Rice straw. BGS, Black gram straw. Value in the rows having different subscript were significantly different $(P<0.05)$ and without superscript were not significant $(P>0.05)$.

The crude protein $(\mathrm{CP})$ requirement per kg live weight was significantly lower $(\mathrm{P}<0.05)$ in $\mathrm{D}_{3}(1.74$ $\mathrm{kg})$, followed by $\mathrm{D}_{2}(3.91)$ and $\mathrm{D}_{1}(5.3 \mathrm{~kg})$. These requirements were substantially higher than the requirement reported by ARC (ARC 1980) for a growing goat (0.388 g CP/gram gain). 


\section{Growth rate}

Body weight of different treatment groups at different interval, average daily weight gain (ADG) and change in metabolic body size is presented in Table 3. There was significant difference $(\mathrm{P}<$ 0.05 ) between diets groups for total weight gain and ADG. The highest total weight gain for an experimental period of 150 days was obtained in $\operatorname{Diet}_{3}(2.94 \pm 0.65 \mathrm{~kg})$, followed by $\mathrm{D}_{2}(1.9 \pm 0.21$ $\mathrm{kg}), \mathrm{D}_{4}(1.76 \pm 0.27 \mathrm{~kg})$ and $\mathrm{D}_{1}(1.62 \pm 0.28 \mathrm{~kg})$. Average daily weight gain was found significantly higher $(\mathrm{P}<0.05)$ in $\mathrm{D}_{3}(19.6 \mathrm{~g} / \mathrm{d})$, followed by $\mathrm{D}_{2}(12.67 \mathrm{~g} / \mathrm{d}), \mathrm{D}_{4}(11.73 \mathrm{~g} / \mathrm{d})$ and $\mathrm{D}_{1}(10.8 \mathrm{~g} / \mathrm{d})$. These growth rates of a growing goats of 6-9 month age were substantially lower than the growth recorded at Goat Research Station, Bandipur over past five years (ARS 2000) that was $39.33 \mathrm{~g} / \mathrm{d}$, and Rasjit and Perez (1980) when animal were fed with 20 percent rice straw with Leucaena and rice bran.

Table 3. Weight gain of goats in different dietary treatments

\begin{tabular}{|c|c|c|c|c|}
\hline \multirow[t]{2}{*}{ Nutrients } & \multicolumn{4}{|c|}{ Diet groups } \\
\hline & $\begin{array}{l}\text { Fodder only } \\
D_{1}\end{array}$ & $\begin{array}{l}\text { RS } 20 \%+ \\
\text { Fodder } 80 \% \\
D_{2}\end{array}$ & $\begin{array}{l}\text { RS } 20 \%+\text { Fodder } \\
(55 \%)+\text { Concentrate } \\
D_{3}\end{array}$ & $\begin{array}{l}\text { RS } 15 \%+\text { Fodder } \\
(80 \%)+\text { BGS }(5 \%) \\
D_{4}\end{array}$ \\
\hline Initial body weight $(\mathrm{kg})$ & $\begin{array}{l}11.5 \pm \\
0.97 \mathrm{a}\end{array}$ & $11.425 \pm 0.95 a$ & $12.46 \pm 1.24 \mathrm{a}$ & $11.8 \pm 0.97 \mathrm{a}$ \\
\hline Final body weight $(\mathrm{kg})$ & $\begin{array}{l}13.12 \pm \\
1.0 \mathrm{a}\end{array}$ & $13.321 \pm 0.11 \mathrm{a}$ & $15.4 \pm 1.7$ & $13.56 \pm 1.17$ \\
\hline Total weight gain $(\mathrm{kg})$ & $\begin{array}{l}1.62 \pm \\
0.28 \mathrm{a}\end{array}$ & $1.9 \pm 0.21 \mathrm{ab}$ & $2.94 \pm 0.65$ & $1.76 \pm 0.27$ \\
\hline Average weight gain (g) & $10.8 \pm 1.87$ & $12.67 \pm 1.38 \mathrm{ab}$ & $19.6 \pm 4.33 b$ & $11.73 \pm 1.78 \mathrm{ab}$ \\
\hline Initial metabolic body size $\left(\mathrm{W}^{0.75}\right)$ & $6.24 \pm 0.59$ & $6.21 \pm 0.87$ & $6.63 \pm 1.10$ & $6.37 \pm 0.87$ \\
\hline Final metabolic body size $\left(\mathrm{W}^{0.75}\right)$ & $6.89 \pm 0.89$ & $6.97 \pm 0.98$ & $7.78 \pm 1.43$ & $7.07 \pm 1.02$ \\
\hline Change in metabolic body size $\left(\mathrm{W}^{0.75}\right)$ & $0.65 \pm 0.26$ & $0.76 \pm 0.16$ & $1.15 \pm 0.51$ & $0.7 \pm 0.20$ \\
\hline
\end{tabular}

Value in the rows having different superscript were significantly different $(P<0.05)$.

The average daily weight gain of goats fed with different rice straw based diets is shown in Figure 1.

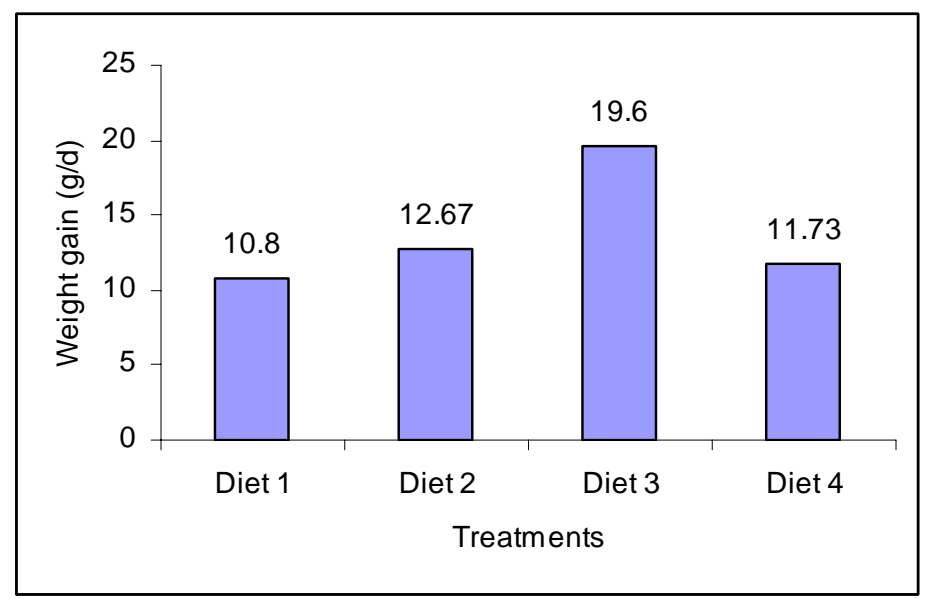

Figure 1. Average daily weight gain of goats fed with different rice straw based diets.

The growth pattern of experimental animals was similar to the expected growth curve of animals (Figure 1). The growth rate of animals of $\mathrm{D}_{3}$ was higher than other groups, while that of Diet 1,2 and $\mathrm{D}_{4}$ were similar. This indicated the importance of incorporating concentrate in the diet that improves the digestibility of nutrients. The decreased growth rate of animals of Diet between 145 to 150 days of trials was due to diarrhea in one animal. From this experiment it could be advised that rice straw can be incorporated in the diet up to 20 percent of dry matter requirement of animals without effect in growth. Though lower growth rate, $\mathrm{D}_{3}$ could be utilized as a maintenance ration in the feed scarcity period. 


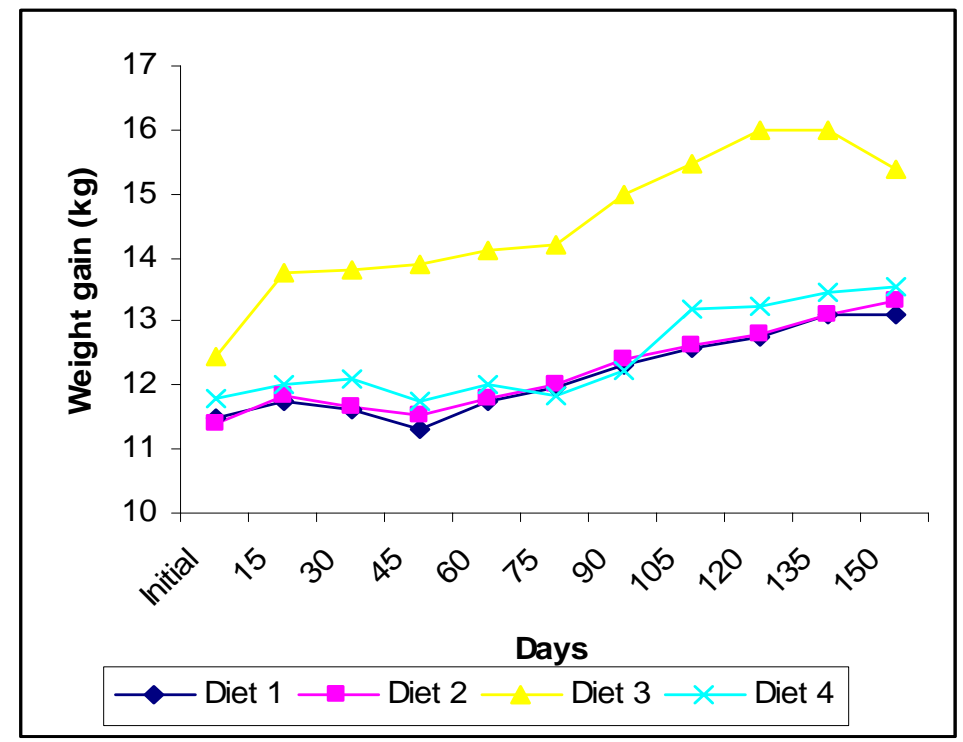

Figure 2. Average body weight gain patterns of goats fed with different rice straw based diets at 15 days interval.

Meat type goat could be raised in stall feeding system by feeding straw up to 20 percent of dry matter requirement in combination of fodder and concentrate at the rate of $1 \%$ body weight. Feeding only with tree foliage is not enough to get higher growth performance in stall feeding management in the Hills of Nepal. Therefore, during the winter, goat can be fed with certain level of rice straw in stall-fed management system.

\section{ACKNOWLEDGEMENTS}

The authors would like to thank to HARP for funding the experiment. The authors are grateful to all the staff of ARS Bandipur who helped to conduct the experiment and to technical staff of Animal Nutrition Division Khumaltar for timely analyzing of feed samples. Special thanks goes to Dr. W. Stewart-Jones, HARP Research Advisor ARS Lumle for his regular visits, supports, comments and moral support, Dr NP Shrestha, Director Livestock and Fish Research, NARC for his encouragement, Professor Dr M Sapkota for helpful comments and regular technical assistance and Dr SM Pradhan for critical comments.

\section{REFERENCES}

Agrawal IS, ML Verma, AK Singh and YC Pandey. 1989. Feeding value of ammonia treated straw in terms of milk production. Indian J. Anim. Nutr. 6:89.

AOAC. 1990. Official methods of analysis. Fourteenth Edition. Association of Official Analytical Chemist, Washington. DC.

ARC. 1980. The nutrient requirement of ruminant livestock. Commonwealth Agriculture Bureoux, Slough, Berk, UK. Pp. 349.

ARS. 2000. Annual report 1999/2000. Agriculture Research Station (Goat), Bandipur, Tanahun. Pp. 4-17.

Chenost M and C Kayouli. 1997. Roughage utilization in warm climates. FAO 135:1-225.

Devendra C. 1988. Nutrition and meat production, Goat meat production in Asia. In: Proceedings of a Workshop (C Devendra, ed), 13-18 March 1988, Tando Jam, Pakistan. Pp. 30-34.

Dixon RM. 1985. Maximizing the rate of fiber digestion in the rumen. In: Proc. of the $6^{\text {th }}$ Annual Workshop IPD. Pp. 49-67.

Goering HK and BS Van Soest. 1970. Forage fiber analysis. Agricultural Hand Book No. 379. USDA, Washington, DC.

Pandey RS. 1997. Fodder and pasture development in Nepal. Udaya Research and Development Service (Pvt) Ltd., Kathmandu. Pp. 4-5. 
Rasjit S, CB Jr. Perez. 1980. Fattening goat with ipil-ipil (Leucaena leucocephala) and rice straw plus rice bran or molasses. Philippine Journal of Veterinary and Animal Science 6:500-507.

Sharma DD, DV Rangnekar and M Singh. 1995. Physical of chemical treatment of fibrous crop residue to improve nutritive value: A review. ICAR Publication. NDRI, India. Pp. 263-276.

Snedecor GW and WG Cochran. 1968. Statistical methods. Sixth Edition. Oxford and IBH Publishing Co., Calcutta, India.

Upreti CR and BK Shrestha. 2006. Nutrient contents of feed and fodder in Nepal. Nepal Agricultural Research Council, Kathmandu, Nepal.

Upreti CR. 2004. Rice bran and leucaena supplementation on the growth and digestibility by goats fed urea treated rice straw. PhD Thesis. CLSU, The Philippines. Pp. 43-44. 